\title{
Anthropology goes to war, again
}

\author{
Lesley Gill
}

\begin{abstract}
Debates about the relationship of anthropology to the U.S. national security establishment are not new, and anthropologists are now forced to confront the issue again. Since the 11 September attacks, the U.S. military has stepped up efforts to recruit anthropologists to fight the so-called "war on terror," and a group of self-identified "security anthropologists" have organized for more recognition and legitimation within the American Anthropological Association. The article considers what is new about the current controversy, and it examines the issues at stake for anthropologists and the people who they study. It argues that anthropologists need to raise anew basic questions about their disciplinary and intellectual endeavors and that they must re-educate themselves on the realities of power.
\end{abstract}

Keywords: anthropologist, culture, ethics, national security, power

We must find ways of educating ourselves in the realities of power.-Eric Wolf

Anthropology has a long, and not entirely wellunderstood, relationship to the national security establishment that has erupted periodically into controversy. ${ }^{1}$ As early as World War I, Franz Boas charged four anthropologists with "prostituting science" because they used fieldwork as a cover for spying in Central America (Boas 1919) and during the Vietnam War era, the participation of anthropologists in counterinsurgency activities generated intense controversy within the American Anthropological Association (AAA). Since the attacks of 11 September 2001, U.S. anthropology is again being drawn into war, as the military solicits anthropologists to fight the so-called "war on terror," especially in Iraq. Some anthropologists have responded favorably to the call, and a group of self-identified "security anthropologists," who work for military and intelligence agencies, have organized to press for more legitimacy within the AAA. The Association is now revisiting an old debate about the appropriate relationship between anthropologists and the national security establishment, and it has created a commission to establish guidelines (Goodman 2006; Nuti 2006). What, we might ask, is new about the current controversy, and what are the issues at stake for anthropologists and the peoples who they study?

When anthropologists last locked horns on this issue, the United States was mired in an unwinnable counter-insurgency war in Vietnam, and a powerful antiwar movement, 
spurred by the draft, mobilized hundreds of thousands of people to oppose U.S. policies in Southeast Asia. The campuses were in turmoil; soldiers were killing their officers in Vietnam; and social movements on the home front were challenging the basis of race, gender, and sexual privilege. Student outrage over the Vietnam War motivated the Student Mobilization Committee to End the War in Vietnam to provide documentation to Eric Wolf, then Chair of the Ethics Committee of the AAA, which linked several social scientists to counterinsurgency activities in Thailand. A conflict erupted within the AAA, after Wolf and committee member Joseph Jorgensen exposed the involvement of U.S. anthropologists (Wolf and Jorgensen 1970; Wakin 1992), and it moved the Association to adopt a new ethics code in 1971 that placed the interests of research subjects above those of all others and sought to hold anthropologists' accountable to a wider public.

Like the late 1960s and early 1970s, the United States today is enmeshed in another unpopular counterinsurgency war that has rapidly surpassed its capacity to either control or win, and the national security establishment is again actively recruiting social scientists. Yet, many anthropologists know very little about the earlier controversy, and much has changed since the early 1970s. The campuses are quiet for the most part. An independent Left has declined since the end of the Vietnam War, and many of the civil rights victories won in the mid-twentieth century are being rolled back. The antiwar movement is spiritless, and torture has become quasi-legal in the armed forces. After some massive demonstrations on the eve of the 2003 U.S. invasion of Iraq, active resistance to the occupation of Iraq has declined, despite opposition by a majority of U.S. citizens, and the Democratic Party, which won control of Congress on a wave of antiwar sentiment in the 2006 elections, has refused to cut funding for the war. There is no longer a draft. The army is a "volunteer" force, and even though the Pentagon has difficulties staffing an occupation with volunteers, the enormous expansion of private military contractors in the aftermath of $9 / 11$ has provided the Bush administration with a private alternative to a draft, which includes the recruitment of mercenaries from around the world. ${ }^{2}$

As the war rages in Iraq, academia is itself under siege. The rise of part-time, untenured positions has eroded job security, making it more difficult for academics to take stands on controversial issues, and unlike the Vietnam War generation, college students today are burdened with debt, which limits their career choices. In addition, right-wing groups, such as Campus Watch and Students for Academic Freedom, bring political pressure to bear on faculty members who do not hold their extreme views, and they encourage students to inform on professors. Since the September 11 terrorist attacks, new scholarship programs that combine intelligence training with anthropology and other social sciences have appeared. These programs, such as the Pat Roberts Intelligence Scholars Program (PRISP), do not publicize the names of scholarship recipients, who may remain anonymous in the classrooms where they study, and they create a kind of debt peonage by requiring students to work for an intelligence agency after completion of their studies (Gusterson and Price 2005).

Clearly, we are living in a reactionary political moment in which the institutional and organizational forms needed to challenge U.S. militarization have weakened. Now a new group of security anthropologists seek greater legitimation in the AAA for their work in a variety of military and intelligence organizations (e.g., Selmeski 2007). Their numbers have grown in recent years for several reasons. Job growth within universities has not kept pace with the creation of often better-paid positions outside the academy, and the security forces advertise a need for "cultural knowledge," as they enlist social scientists in the struggle to gain control over the insurgency in Iraq. Moreover, the AAA has made more room for academic and nonacademic anthropologists doing proprietary or confidential research, after the revision, in 1998, of its ethics code and the removal of the condemnation of secret research. The provision of 
confidential information about research subjects to an employer or sponsor who wants to control them is under reconsideration as the imperatives of new neoliberal research agendas undermine established ethical principles and professional practices (Berreman 2007; Gusterson 2006).

There is an urgent need to raise again fundamental questions about our intellectual and disciplinary endeavors. When a corporation can own the results of anthropological research, or a defense agency can restrict access to them, is the goal of anthropology to speak to a broadly defined scholarly and lay public subverted by the drive for profits and the quest for geopolitical power? As anthropologists become the agents of employers, do they surrender important ethical decisions to others? What responsibilities do anthropologists have for their research subjects? Although there was once broad agreement on these issues, the debate on anthropological ethics has reopened under pressure from nonacademic practitioners.

It is not clear how many security anthropologists there are, nor do we understand the full range of activities in which they are engaged. Yet, those individuals who speak in public represent a diverse group. Some anthropologists unabashedly harness social science to the U.S. war effort and assist the military in developing more effective counterinsurgency strategies (e.g., Kilkullen 2006; McFate 2005). These anthropologists contribute to U.S. counterinsurgency tactics without any critical consideration of the appropriateness or the legality of the U.S. occupation of Iraq, nor do they evaluate the claims of the insurgents (González 2007). Others are more circumspect. They argue that anthropology has much to contribute to the national security establishment, and they worry that if anthropologists do not work with military organizations, contractors, and think-tanks to contribute "nuance and balance to the crafting of national security policy" (McNamara 2006: 13), policy makers with less cultural sensitivity and expertise will do so (McNamara 2006; Selmeski 2007; Simons 1999). Such arguments demonstrate considerable naïveté about power.

\section{Power and Realpolitik}

In 1969, Eric Wolf wrote, "the dominant intellectual issue of the present is the nature of public power and its exercise" (Wolf [1969] 1972: 252). He went on to lament, "Neither in the nineteenth century nor in the first half of the 20th century ... did American anthropology as such come to grips with the phenomenon of power. It is with this legacy of unconcern that we enter the period of the present" Wolf [1969] 1972: 257). Yet, because of the social and political ferment of the Vietnam era, and the scholarship of Wolf and others, much of the discipline did start to grapple with power. Drawing on the work of Marx and Foucault, many anthropologists developed important insights into how power shaped the birth of anthropology, its relationship to the colonial enterprise and contemporary U.S. imperialism, the creation of the Third World, and the subjects of anthropological research (e.g., Asad 1973; Ferguson 1994; Gough 1968; Wolf 1982). Contemporary security anthropologists ignore these insights and, in many cases, they embrace outdated notions of culture as a bounded, isolated unit (e.g., Simons 1997) that is coterminous with membership in a nation state (e.g., McFate 2005). By so doing, they ignore the processes of power that gave rise to contemporary ensembles of beliefs, practices, and relationships and the connections among them. Yet, worse than the superficial-even trite-grasp of the culture concept is the presumption that, armed with little more than arguments about culture, especially "Arab culture" or "Iraqi culture," they can change national security policy from within the national security establishment itself. This constitutes a misunderstanding of how power operates in the most secretive, hierarchical institutions in the world, a realm in which they claim considerable expertise.

It is extremely doubtful that national security agencies would listen to, much less retain, an anthropologist who is highly critical of their policies; indeed, the forced retirement of General Antonio Taguba for his critical report of 
the Abu Ghraib scandal demonstrates that even highly placed critics are not immune to reprisal (Hersh 2007). Most state agencies-not just the military-and private contractors hear what they want to hear, and the kinds of behavior, beliefs, and policies that are possible, impossible, and unimaginable within them are shaped by highly unequal relationships of power that link agencies and their personnel to thinktanks, political coalitions, and financial constituencies elsewhere. Disrupting or reshaping national security institutions requires the construction of alliances and coalitions to bring political pressure to bear on them, but there is unfortunately little discussion among the security anthropologists of the tactics necessary to build this kind of opposition. Without some sense of how these agencies can be dismantled or substantially transformed, what is left is an ill-conceived, heroic individualism that lacks an appreciation of realpolitik at precisely a time when observers on both the Left and Right acknowledge that the United States possesses an empire, and the seamy side of that empire is increasingly revealed.

U.S. military and intelligence organizations have expanded the power and wealth of the United States over at least the last half century by killing, manipulating, and impoverishing the peoples who anthropologists traditionally study; indeed, the raison d'etre of a militaryand being a soldier-is to kill. Yet, the profoundly political work of security anthropologists is obscured by the assumption that national security is reducible to a series of technical problems that a well-intentioned, expert anthropologist can address with a more nuanced understanding of culture. ${ }^{3}$ The anodyne designation security anthropologist conveys little of the fear and revulsion with which people in many war-torn areas of the world view civilians who hand over unauthorized information to the security forces. In Colombia, for example, such individuals are regarded as informers and unsparingly labeled sapos (frogs), soplones (stool pigeons), and orejas (ears). Anthropologists as informers place at risk both the people they study and their professional colleagues.
Security anthropologists move away from a long anthropological tradition of siding with the underdog, as they place anthropology at the service of the national security state. Although anthropology emerged from the colonial project and contributed at times to it, researchers have tried to make their work useful to the subaltern since at least the time of Boas. They have also made efforts to advocate for them, even as they grapple with the divisions and forms of inequality that structure relations among subalterns and between them and dominant groups. In addition, following the urging of Laura Nader to "study up" (Nader 1972), anthropologists have placed corporations, development agencies, financial firms, and even national security institutions under scrutiny. They have done so not only to ask better questions about how society works; they have studied the powerful to understand inequality and how relationships of inequality create "haves" and "have-nots" and continually reproduce poverty, marginalization, discrimination, and human rights abuses. Indeed, research into highly unequal relationships of inequality has given rise to questions about the limits of informed consent. How, asks Bourgois, do anthropologists reconcile rapport building and participant observation among the powerful with informed consent, if they hope to document how corporations, state security forces, landlords, and so on, exploit and abuse people (Bourgois 1990)? It is thus with a view "from the bottom up" that anthropologists have placed the beliefs and practices of the powerful under analytic scrutiny.

Security anthropologists suggest that they are uniquely situated to offer insights into the workings of national security institutions. Yet, the question that immediately arises is for whom are they willing to provide these insights? Is it now ethical to study the powerful in order to increase their power and with no consideration of the consequences for the subaltern? Nader cautioned anthropologists that "we cannot, as responsible scientists, educate 'managers' without at the same time educating those being managed" (Nader 1972: 294), but it is 
extremely doubtful that the security anthropologists would brief Iraqis, Afghanis, Colombians, New Orleans residents, undocumented immigrants, and others about how U.S. state security forces operate. To do so would place their jobs at risk and expose those with secret security clearances to possible criminal prosecution. It is therefore important to distinguish between "studying up" from a position in which the researcher can negotiate an autonomous relationship with the research subject and circulate research results freely, and "being up" ${ }^{4}$ in a position where critical analysis can affect one's livelihood and bad ideas are protected by secret security classifications. ${ }^{5}$

Perhaps because anthropologists - unlike economists and political scientists-have long been marginalized from the halls of power, the security anthropologists find comfort in the conceit that the military's widely asserted interest in" "culture" signals the arrival of anthropology to the inner sanctum of empire and a new recognition for people like themselves. Yet, the national security establishment is less enamored with anthropology or culture per se than in developing new ways to control people. The embrace of "culture" has nothing to do with expanding knowledge and understanding of the world's peoples; culture is viewed in the odorous language of the military as a "force multiplier," that is, a means to enhance combat effectiveness by exploiting and manipulating others. National security bureaucrats have little interest in critical analysis and open discussion, as they engage in a desperate, hyper-applied form of problem solving that generates "products" and deployable "tools." 5 Such reductionist research is in keeping with the kind of behavioral social science that flourished during the Cold War and generated investigations that displayed a contempt for complexity, ambiguity, and anything that could not be quantified and measured (Robin 2001).

Anthropologists are not the only social scientists fighting the war on terror. The American Psychological Association (APA), for example, is involved in a divisive fight over the participation of psychologists in interrogations at mili- tary detention centers, such as Guantánamo, and it refuses to follow the lead of the American Medical Association and the American Psychiatric Association, which passed resolutions that prohibit members from participating in interrogations. The Pentagon is now reportedly using psychologists instead of psychiatrists in its interrogations, and some APA members, who are upset with their association's position, are withholding dues. $^{7}$

Psychologists, like anthropologists, are obliged to do no harm, and the CIA argues that psychologists help to make interrogations safer and more effective. Yet, Leonard Rubenstein, the Executive Director of Physicians for Human Rights, says that the CIA's argument is contradictory because the participation of psychologists "tends to ratchet up the harshness of interrogations [and] leads directly to torture because it ... validates the worst interrogation techniques". ${ }^{8}$ Anthropologists should ask how they, too, might aggravate the human rights abuses of the national security state by lending it a veneer of professional respectability. They would do well to consider the example set by Syracuse University geography professor Don Mitchell, when he was asked to give "practical advice" to the students in a national security studies program run by the university and supported with a grant from the U.S. Department of Defense. Mitchell assured them that he did not doubt their good intentions but insisted that he and thousands of other people like him actively resisted the construction of the American Empire and disapproved of the collusion of national security bureaucrats like themselves with it. His practical advice to the students was "Remember who we are" (Mitchell 2005).

Anthropology can also serve as an example of principled opposition to empire; indeed, there is much in the canon that already does, but anthropologists need to re-educate themselves about the realities of power. Marx observed that important historical events have a way of repeating themselves: first as tragedy, then as farce. Likewise, waging an old debate about our relationship to the national security 
state can become a charade if we allow the creeping militarization of the field to continue.

\section{Acknowledgments}

Thanks to Andy Bickford, Gus Carbonella, and Angelique Haugerud for their critical comments on earlier versions of this piece. And thanks to Rob Albro for discussing many of the issues with me.

Lesley Gill teaches anthropology at American University. She is the author of the School of the Americas: Military training and political violence in the Americas (2004), and she is currently conducting research on political violence and neoliberal economic restructuring in Colombia. E-mail: lesleygill@optonline.net.

\section{Notes}

1. The relationship between anthropology and the national security establishment has been most thoroughly explored by David Price (e.g., 2004; 2007; forthcoming). See also Nugent (forthcoming).

2. On Donald Rumsfeld's last day in office, the ratio of active-duty U.S. soldiers to private contractors deployed in Iraq was almost one to one (Merle 2006). See Skahill (2007) for a valuable description of the mercenary firm Blackwater and the explosion of private military firms in the aftermath of September 11. See also Singer (2003).

3. The tendency to reduce complex social, political, economic, and cultural issues to technical problems that can be solved through various forms of social engineering is widespread in applied research. Ferguson, for example, has examined this phenomenon in the development industry (1994). The stakes, however, are much higher when national security agencies employ such reductionist logic to kill and manipulate people.

4. Thanks to Gus Carbonella for this felicitous notion.

5. See Price (2006) for more discussion of the dangers and pitfalls of secret research.
6. I thank Andy Bickford for this observation.

7. See the debate that took place between APA president Dr. Gerald Koocher, Dr. Steven Reisner, an APA member who opposes the current policy, and Dr. Stephen Xenakis, a military psychiatrist on Democarcy Now, 16 June 2006. www.democracynow.org8. Stated on Democracy Now, 1 June 2007.

\section{References}

Asad, Talal, ed. 1973. Anthropology and the colonial encounter. London: Ithaca Press.

Berreman, Gerald. 2007. Ethics versus 'realism' in anthropology. In Ethnographic fieldwork: An anthropological reader, ed. Antonius C.G.M. Robben and Jeffrey A. Sluka, 298-315. Malden, MA: Blackwell Publishers.

Boas, Franz. 1919. Scientists as spies. The Nation, 20 December: 797.

Bourgois, Philippe. 1990. Confronting anthropological ethics: Ethnographic lessons from Central America. Journal of Peace Research 27 (1): 43-54.

Ferguson, James. 1994. The anti-politics machine: 'development', depoliticization, and bureaucratic power in Lesotho. Minneapolis, MN: University of Minnesota Press.

González, Roberto. 2007. Towards mercenary anthropology? The new US army counterinsurgency manual FM 3-24 and the militaryanthropology complex. Anthropology Today 23 (3): 14-19.

Goodman, Alan. 2006. Engaging with national security. Anthropology News, February: 63.

Gough, Kathleen. 1968. Anthropology and imperialism. Monthly Review, April: 12-24.

Gusterson, Hugh. 2006. Where are we going? Engaging dilemmas in practicing anthropology. Anthropology News 47 (5): 26.

Gusterson, Hugh, and David Price. 2005. Spies in our midst. Anthropology News, September: 39-40.

Hersh, Seymor. 2007. The general's report. The New Yorker, 25 June. www.newyorker.com/ reporting/2007/06/25/070625fa_fact_hersh.

Kilkullen, David. 2006 Twenty-eight articles: Fundamentals of company-level counterinsurgency. Military Review (May-June): 103-108.

McFate, Montgomery. 2005. Anthropology and counterinsurgency: The strange story of their 
curious relationship. Military Review (MarchApril): 24-38.

McNamara, Laura. 2006. Where are the anthropologists? Anthropology News, October: 13.

Merle, Ranae. 2006. Census counts 100,000 contractors in Iraq. Washington Post, 5 December.

Mitchell, Don. 2005. You who are the bureaucrats of empire, remember who we are. Antipode 37 (2): 203-207.

Nader, Laura. 1972. Up the anthropologist: Perspectives gained from studying up. In Reinventing Anthropology, ed. Dell Hymes, 284-311. New York: Vintage Press.

Nugent, David. Forthcoming. Social science knowledge and military intelligence: Global conflict, territorial control, and the birth of area studies during World War II. Anuario Anthropologico.

Nuti, Paul J. 2006. US security and intelligence commission charts ethnographic course. Anthropology News, December: 19.

Price, David. 2004. Threatening anthropology: McCarthyism and the FBI's surveillance of activists anthropologists. Durham, NC: Duke University Press.

. 2006. Critiquing silence: On the impropriety of secret research and covert ties to intelligence agencies. Paper presented at the Annual Meeting of the American Anthropological Association, San Jose, California.

. 2007. Buying a piece of anthropology,

Part 1: Human ecology and unwitting anthropological research for the CIA. Anthropology Today 23 (3): 8-13.
Forthcoming. Anthropological intelligence: The use and neglect of American anthropology during the Second World War. Durham, NC: Duke University Press.

Robin, Ron. 2001. The making of the Cold War enemy: Culture and politics in the military-intellectual complex. Princeton, NJ: Princeton University Press.

Selmeski, Brian. 2007. Who are the security anthropologists? Anthropology News, May: 11-12.

Simons, Ana. 1997. The company they keep: Life inside the US special forces. New York: Free Press.

1999. War: back to the future. Annual Review of Anthropology 28: 73-108.

Singer, P. W. 2003. Corporate warriors: The rise of the privatized military industry. Ithaca, NY: Cornell University Press.

Skahill, Jeremy. 2007. Blackwater: The rise of the world's most powerful mercenary army. New York: Nation Books.

Wakin, Eric. 1992. Anthropology goes to war: Professional ethics and counterinsurgency in Thailand. Center for Southeast Asian Studies. Monograph 7. Madison, WI: University of Wisconsin.

Wolf, Eric. [1969] 1972. American anthropologists and American society. In Reinventing Anthropology, ed. Dell Hymes, 251-64. New York: Vintage.

- 1982. Europe and the people without history. Berkeley: University of California Press.

Wolf, Eric, and Joseph G. Jorgensen. 1970. Anthropology on the warpath in Thailand. New York Review of Books 15 (9). www.nybooks.com/ articles/10763. 